Meta

Journal des traducteurs

Translators' Journal

\title{
Partial Dubbing
}

\section{Paul Hendrickx}

Volume 29, numéro 2, juin 1984

URI : https://id.erudit.org/iderudit/003043ar

DOI : https://doi.org/10.7202/003043ar

Aller au sommaire du numéro

Éditeur(s)

Les Presses de l'Université de Montréal

ISSN

0026-0452 (imprimé)

1492-1421 (numérique)

Découvrir la revue

Citer cette note

Hendrickx, P. (1984). Partial Dubbing. Meta, 29(2), 217-218.

https://doi.org/10.7202/003043ar

Ce document est protégé par la loi sur le droit d'auteur. L’utilisation des services d'Érudit (y compris la reproduction) est assujettie à sa politique d'utilisation que vous pouvez consulter en ligne.

https://apropos.erudit.org/fr/usagers/politique-dutilisation/
Cet article est diffusé et préservé par Érudit.

Érudit est un consortium interuniversitaire sans but lucratif composé de l’Université de Montréal, l'Université Laval et l'Université du Québec à Montréal. Il a pour mission la promotion et la valorisation de la recherche. https://www.erudit.org/fr/ 


\section{PARTIAL DUBBing}

In order to make a film accessible to those who do not understand the language that is spoken in it, two methods are currently used : subtitling and dubbing (or postsynchronisation). The advantage of dubbing is that the viewer can watch the film as usual. It is however, a rather elaborate and expensive procedure and also, the actors lose much of their authenticity : an English speaking Yves Montand or a German speaking Grace Kelly is not the real thing. Besides, it is somewhat strange to hear a person say "cabbage" while seeing his lips forming the word "chou". Subtitling, on the other hand, is inexpensive and relatively easy to carry out, but it has several disadvantages. The written text covers up part of the picture, you often need to have good eyesight to make it out - especially on a small television screen
-, and it is altogether useless to people who cannot read fast enough or who cannot read at all (it is estimated that there are over a thousand million illiterates in the world). A further major objection to subtitling is that the viewer's attention is drown away from the actual performance of the players - and of the director.

In the Netherlands, in the Flemish part of Belgium and in many other small countries, subtitling is most often the only form of translation available. The English, French and German public are very reluctant to accept subtitles, and insist on synchronized translation. In Italy the importation of films that are not dubbed in Italian has been made il legal. Furthermore, opera and stage-plays are rarely accompanied by any form of translation. Finally, problems arise in many homes when a programme on the telly is presented in a language that is not equally well understand by all members of the family.

An alternative form of translation would the refore be very welcome and the method described below might be an acceptable solution, at least in certain cases.

I propose to call it "partial dubbing" or "concise synchronisation". It would consist in adding to the original sound track a spoken text giving the necessary information in the target language without providing a full translation of the dialogue. Although no serious study has been made so far of the possibilities of this method, it has several obvious advantages. In the first place, it is relatively easy to carry out and therefore economical. Secondly, it would allow opera and stage-plays to be provided with a kind of simultaneous translation, possibly by means of the very light portable electronic devices that are now available at relatively low cost, and which are already extensively used for simultaneous interpretation in conference halls.

Considerable research will certainly be needed to find the techniques required to put this idea into practice. However, experiments on a small scale have already allowed me to reach the following conclusions :

1.The method is feasible and the result can be very satisfactory.

2.The cost is low, especially since the presenters need not be professional actors.

3.It is possible to make translations in several languages available at the same time.

4.Total suppression of the original soundtrack is, in most cases, not advisable, but it is not certain when and to what extent the dubbing signal should be allowed to drown the original sound. In any case, the fact remains that part of the advantage resulting from the viewer being able to concentrate on the image rather than on a written text is partially annihilated by the fact that the original sound escapes his notice whenever he is listening to the translation. In order to compensate for this, it is necessary to make full use of the silent passages in the original dialogue and to make the translated text as short as 
possible, which means that any information that is not essential should, in principle, be left out. Precisely to what extent this can be done without impairing the validity of the production is still an open question. In many cases, however, it appears that the dialogues can be considerably shortened without undue loss of quality.

5.Dialogue may possibly even be replaced partly or entirely - by a (shorter) description of what is going on, or it may simply be reproduced in indirect speech.

6.Finally, careful consideration should be given to the rate of speed at which the "translation" is delivered.

The following additional observations may also be of interest.

- Partial dubbing is not possible in all cases, nor, for that matter, is it always advisable.

- Its application will not be satisfactory unless the right technique is used in the proper way and adapted to each individual case.

- The working method will have to be modified according to the length and importance of the dialogues and the type of subject : screen play, documentary, opera, etc.

- In order to determine the nature and length of the new text, the time of insertion, the volume of the sound, etc., a completely new script will have to be produced in close collaboration with the translator. The writer of this new script and the director will need to be perfectly familiar with the play, and all those involved in the adaptation will require considerable skill, imagination and ingenuity.

- With the currently available stereo systems of sound reproduction, it is now possible to add to the original sound track one or more dubbing texts, which those members of the audience who do not understand the language of the original can then receive through ear-phones without disturbing those who are listening to the original sound.

- Extensive research will be necessary to provide the right answers to many questions, such as are the following, which still open.

a) In which cases should be dubbing text be presented by more than one person in view of differentiating the various actors, i.e. to what extent can the lines of various actors - men, women, children, etc. be rendered by one person?

b) When is it advisable to maintain the original intonation of a dialogue rather than read out the "translation" in a neutral tone? The latter is certainly the simplest, easiest and less expensive solution, but it may result in objectionable monotony of the presentation.

c) Authors and actors may not approve of this new type of "translation". They should consider, however, that some of the quality of the original is lost in any form of translation, and that an imper- fect adaptation may be preferable to no translation at all.

Considering the large numbers of people throughout the world who watch film and television programmes without properly understanding the language used in them, and considering also the numerous cases in which the appreciation of films, etc., is greatly reduced or made altogether impossible because of the inefficiency of the existing methods of translation, there can be no doubt about the desirability of looking more closely into the possibilities of partial dubbing.

PAUl HENDRICKX 